\title{
Contribution to Risk Analysis of a Standard Brewery: Application of a Hygiene Assessment System Survey
}

\author{
António Raposo ${ }^{* 1}$, Jairo Salazar², Esteban Pérez², Esther Sanjuán², Conrado Carrascosa² ${ }^{2}$ Pedro Saavedra ${ }^{3}$, Rafael \\ Millán $^{2}$ \\ ${ }^{1}$ Centro de Investigação Interdisciplinar Egas Moniz, CiiEM. Instituto Superior de Ciências da Saúde Egas Moniz, ISCSEM. \\ Quinta da Granja. Monte de Caparica. 2829-511 Caparica. Portugal \\ ${ }^{2}$ Department of Animal Pathology and Production, Bromatology and Food Technology, Faculty of Veterinary, Universidad de \\ Las Palmas de Gran Canaria, Trasmontaña s/n, 35413 Arucas, Spain \\ ${ }^{3}$ Department of Mathematics, Universidad de Las Palmas de Gran Canaria, Mathematics Building, Campus Universitario de \\ Tafira, 35018 Las Palmas de Gran Canaria, Spain \\ * Corresponding author e-mail: ajasr @hotmail.com
}

\begin{abstract}
Beer is a food product with a high consumption in Gran Canaria and the brewery industry is also present in this island. In order to carry out this study, it was designed a survey to assist in the assessment of risks from the facilities and infrastructures of the brewery, the raw materials used in the beer production and the HACCP (Hazard Analysis and Critical Control Points) plan.
\end{abstract}

An initial assessment of various aspects of the industry has been conducted at the beginning of hygienic-sanitary counselling and a second assessment on the effects could manifest such counselling. It was observed that there was an increase score in most of points tested following the guidance in the interval of time between the both assessments. HACCP

Keywords- Assessment; Beer; Brewing; Counselling;

\section{INTRODUCTION}

In Canary Islands the climate is always warm throughout the year and there is a strong influx of tourists that make the beer has an important role in this region. According to the "Socio-economic report of the Beer Industry in Spain 2010", prepared by the Ministry of Environment and Rural and Marine Affairs and the Association of Brewers of Spain, with an increase of $2.9 \%$, Canary Islands, along the northwest peninsula, the Spanish zone where more the consumption of beer was increased in $2010^{[1]}$. This preponderance of the brewing industry in the region was a factor that led us to develop a study on this subject.

Beer, a brewed beverage, is one of the most popular drinks worldwide ${ }^{[2]}$. It is a drink obtained by the alcoholic fermentation by yeast selected from a mash of malted barley, alone or mixed with other starches converted into sugars by enzymatic digestion with added hops and / or its derivatives and subjected to a cooking process ${ }^{[3]}$.

Of course, both food safety (assurance that food will not cause harm to the consumer when it is prepared and/or eaten according to its intended use) and food hygiene (all conditions and measures necessary to ensure the safety and suitability of food at all stages of the food chain) of this product must be in line with the standards required by the regulations and food industry.

Effective hygiene control, therefore, is vital to avoid the adverse human health and economic consequences of foodborne illness, foodborne injury, and food spoilage. Everyone, including farmers and growers, manufacturers and processors, food handlers and consumers, has a responsibility to assure that food is safe and suitable for consumption $^{[4]}$.

The brewing of beer is an ancient art. The oldest ancient records suggest that formal brewing dates back to about 6000 B.C. in ancient Babylonia ${ }^{[5]}$ and is considered one of the most safe and hygienic food products, especially because alcohol concentration and compounds derived from hops. However, these claims are valid in terms of compliance required by the management system of food quality and safety ${ }^{[6,7]}$.

While beer provides a very stable microbiological environment, a few niche microorganisms are capable of growth in malt, wort and beer. Growth of mycotoxinproducing fungi during malting, production of off-flavours and development of turbidity in the packaged product due to the growth and metabolic activity of wild yeasts, certain lactic acid bacteria (LAB) and anaerobic Gram negative bacteria, impact negatively on beer quality. It follows that any means by which microbial contamination can be reduced or controlled would be of great economic interest to the brewing industry and would serve the public interest. There has been an increasing effort to develop novel approaches to minimal processing, such as the exploitation of inhibitory components natural to raw materials, to enhance the microbiological stability of beer ${ }^{[8]}$.

The raw materials used and the nature of the biochemical and physicochemical processes taking place along the entire technological process of production of beer require keeping under strict control of all process parameters. This is because the concept of quality in recent decades has undergone significant changes. Quality is 
increasingly aware and this is not just a problem of a "Quality control department”, but a concern of all company staff. The technical problem of quality has become more and more into a management problem. Thus, the production units increasingly feels the need to shift from control of compliance of product quality (good separation of the products improper), to quality management (coordinated activities that enable control of an organization in terms of quality) ${ }^{[6] .}$

This means that the entire organization and in all activities do the best to achieve safe products and with high quality (marketing, design, procurement, production, sales, services, etc.). According to established documents, numerous types of beer and beer-like beverages from different grains were industrially manufactured in some ancient countries, such as Egypt, Rome, China, India, and Iran ${ }^{[5]}$. The basic ingredients for beer remained unchanged over the centuries: barley, malt, water, hops and yeast. The process for brewing normal beer (Figure 1) consists essentially of the following steps: malting barley by germination, crushing the malted barley to create a "grist", adding water to the grist to create a mash, separating the resulting aqueous extract known as "wort", boiling the wort with hops, cooling and clarifying the wort, fermenting the wort with yeast (primary fermentation) to produce "green" or "young" beer, maturing or "lagering" the fermented young beer by means of "secondary fermentation" again using yeast, filtering, pasteurizing and finally, packaging the beer. Beer characteristics can be influenced by the variety of barley used for the brewing and the conditions applied in each of the above steps ${ }^{[9]}$.

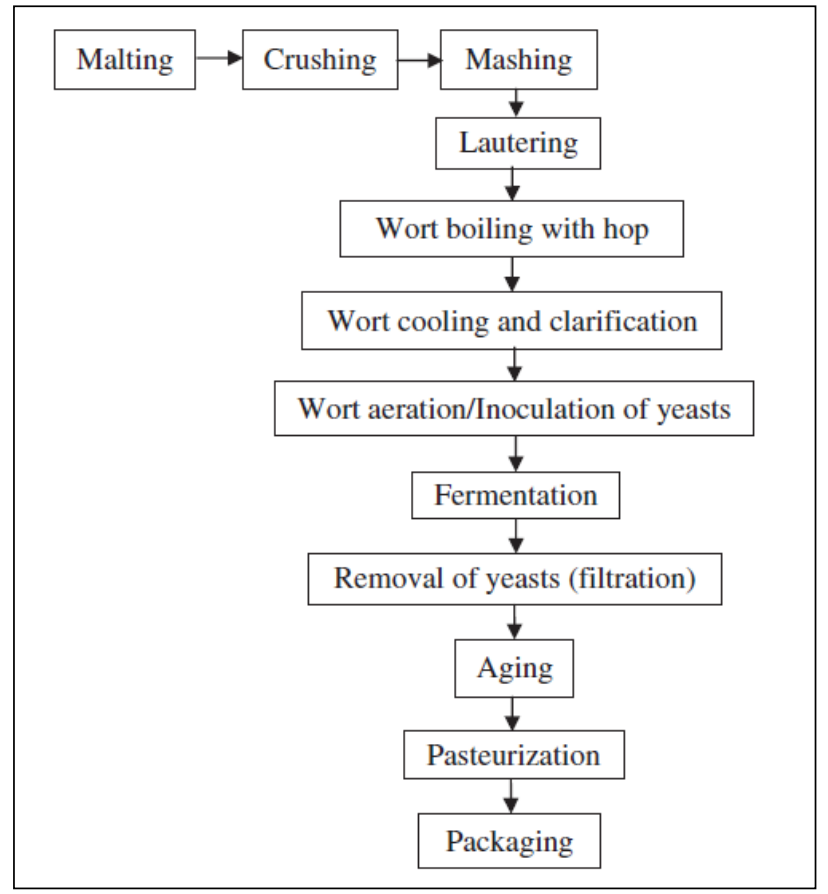

Fig. 1 Brewing process flow chart

Malted barley can be partially replaced by adjunct grains (such as maize and rice). Sugar, various syrups, starchcontaining mixture, and different types of adjuncts might also be added to the beer ${ }^{[10,11,12,13]}$. Normal-/regular- /conventional beer contains 2.5-13\% (v/v) ethanol. Most beers produced worldwide have alcohol content in the range of $3-6 \%(\mathrm{v} / \mathrm{v})^{[12,14]}$. Considering the alcohol content of beers, they can be classified into three types, namely: lowstrength (containing about 2-3\% alcohol), medium/average-strength (about 5\% alcohol), and high strength/ strong (about $6-12 \%$ alcohol) beers ${ }^{[15]}$. Low-alcohol beer contains a maximum of $0.5-1.5 \%$ (w/v) ethanol (Germany) [16]. This type of beer might be known as "zero-alcohol" beer. The language of "Nearly alcohol-free" might be used when the alcohol content is within $0.05-0.5 \%(\mathrm{v} / \mathrm{v})^{[15]}$.

General process steps, hazards, control, critical control point (CCP) parameters and monitoring procedures of brewing are summarized in Table I.

TABLE I GENERAL PROCESS STEPS, HAZARDS, CONTROL, CRITICAL CONTROL POINT (CCP) PARAMETERS AND MONITORING PROCEDURES OF BREWING

\begin{tabular}{|c|c|c|c|c|}
\hline Process step & Hazards & Control & $\begin{array}{c}\text { CCP } \\
\text { Parameter }\end{array}$ & $\begin{array}{l}\text { Monitoring } \\
\text { procedures }\end{array}$ \\
\hline Malting & $\begin{array}{l}\text { Chemical } \\
\text { Physical } \\
\text { Microbiological }\end{array}$ & $\begin{array}{l}\text { Use of indirect } \\
\text { heating systems, } \\
\text { controllow-NO= } \\
\text { burners } \\
\text { Control of time, } \\
\text { temperature and } \\
\text { RH } \\
\text { Proper handling } \\
\text { operations after } \\
\text { production }\end{array}$ & $\begin{array}{l}\text { NDMA (1) } \\
\text { production } \\
\text { during kilning } \\
\text { Colour and flavour } \\
\text { development } \\
\text { Mycotoxin } \\
\text { production }\end{array}$ & $\begin{array}{l}\text { Continuous } \\
\text { checking the } \\
\text { area, specific } \\
\text { analyses } \\
\text { Continuous } \\
\text { monitoring of } \\
\text { processing } \\
\text { conditions } \\
\text { Visual inspection } \\
\text { of fungi } \\
\text { development, } \\
\text { HPLC, ELISA, } \\
\text { EPS analysis }\end{array}$ \\
\hline
\end{tabular}

\begin{tabular}{|c|c|c|c|c|}
\hline Mashing & Chemical & $\begin{array}{l}\text { Control of } \\
\text { temperature, CIP }\end{array}$ & $\begin{array}{l}\text { NDMA } \\
\text { production, } \\
\text { detergent } \\
\text { residues }\end{array}$ & $\begin{array}{l}\text { Continuous } \\
\text { recording of the } \\
\text { processing }\end{array}$ \\
\hline Lautering & Chemical & $\begin{array}{l}\text { Schadule } \\
\text { Inspaction, under } \\
\text { plate cleaning }\end{array}$ & ATNC (2) & $\begin{array}{l}\text { Microbiological } \\
\text { and chemical } \\
\text { analyses }\end{array}$ \\
\hline Boiling & Chemical & $\begin{array}{l}\text { Corract use of } \\
\text { boiler treastment } \\
\text { chemicals }\end{array}$ & $\begin{array}{l}\text { Contamination } \\
\text { with detergents }\end{array}$ & CIP system \\
\hline Fermentation & Microbiological & $\begin{array}{l}\text { Aeration of wort, } \\
\text { use of yeast for } \\
\max 6 \\
\text { generations } \\
\text { Inspection of CIP } \\
\text { system and } \\
\text { equipment }\end{array}$ & $\begin{array}{l}\text { Poor yeast } \\
\text { viability, "stuck" } \\
\text { fermentation } \\
\text { Lactobacilli, actic } \\
\text { acid bacteria } \\
\text { and wild yeasts }\end{array}$ & $\begin{array}{l}\text { Yesst } \\
\text { concentration, } \\
\text { fermentability, } \\
\text { O: concentration } \\
\text { in the wort } \\
\text { Plate count } \\
\text { method, or a } \\
\text { rapid detection } \\
\text { method }\end{array}$ \\
\hline
\end{tabular}




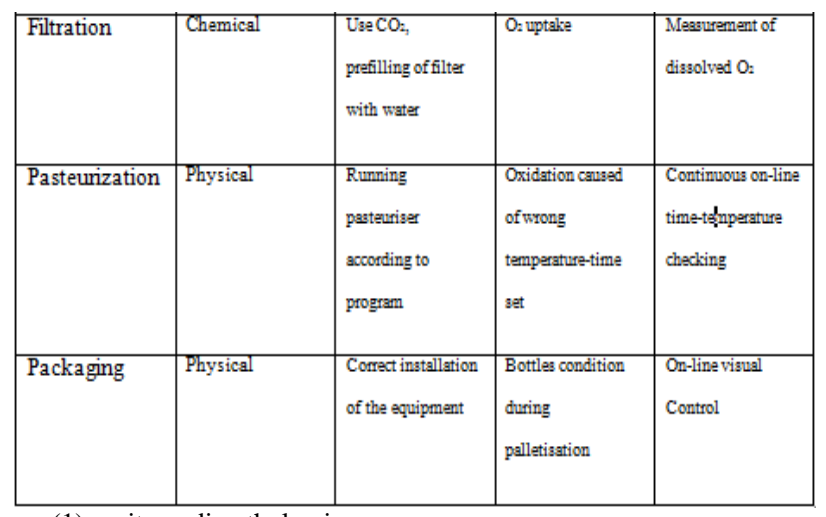

(1) nitrosodimethylamine

(2) Apparent Total $N$-nitrous compounds

Since the entry into force of Council Directive 93/43/EEC of 14 June 1993 on the hygiene of foodstuffs ${ }^{\text {[17] }}$ is mandatory the introduction of HACCP in all businesses food sector. This has led to the development of a work system whose effectiveness, until now, has not always been satisfactory, testing the system of self-control acquired by each of these brewing establishments.

The specific food characteristics of one concrete center (brewery) have led us to raising an investigation of practical immediate interest that was answering to the possible requirements demanded by modern processors centers, demanding basic measures of quality and self-control.

The specific technical objective directly related to the previous approach was to assess the hygienic-sanitary conditions of the brewing center.

The main goal of this study was to obtain initial hygienic-sanitary values of one determined industry and to assess the effect of counselling on the values obtained in a second assessment carried out in the same industry of reference one year later in order to separate the acceptable from non-acceptable. With the results of the second survey it will be possible to approve or not the hygienic-sanitary state of the aforementioned industry.

\section{MATERIALS AND METHODS}

In this study, it was developed a survey in order to assist in the assessment of risks from the facilities and infrastructure of the brewery, the raw materials used in the beer production and the HACCP (Hazard Analysis and Critical Control Points) plan. It was developed a quantitative and qualitative analysis of the results across the statistical and interpretive methodology.

To collect the information it was developed a survey, through meetings with staff responsible for implementation of HACCP in the brewery, and specialists from OHAPA (Food Safety and Hygiene Research Centre) of the Veterinary Faculty of ULPGC (University of Las Palmas de Gran Canaria) that would allow the assessment of the following generic headings:

a) Raw materials (malt, hops, yeast and water) and food,

b) Facilities and infrastructures,

c) HACCP.
Regarding raw materials, it is important to mention that two kinds of barley malt were used (Pilsen and high-roasted) and the yeast Saccharomyces carlsbergensis was applied. This yeast was originated from Holland and it was received by the brewery in one slant agar vial which was activated at a temperature of $6^{\circ}$ to $10^{\circ} \mathrm{C}$ for 8-10 days. It was also used for the production of beer, hop pellets type 90, Nugget variety with 12.5 - 14.5\% of alpha acid and $4-6 \%$ of beta acid which was received at the brewery in tins of $500 \mathrm{~g}$ from Czech Republic. The water constituent of the beer was from the public network, being treated through a process of decalcification through Ionic membranes exchange resins and a subsequent decarbonization with reverse osmosis.

In this survey were developed closed questions (items) and weighted to give an insight into what we want to assess through a series of data collected in the field in an orderly and systematic form.

In order to be able to assess the hygienic-sanitary conditions of the brewery, to every item it was given punctuation according to relative importance in an environment of risk analysis, later to describe and in tables and graphs the obtained information, hereby, we have the response to the hypotheses raised along the work.

To carry out these surveys, we take as basis the hygiene assessment system (HAS) ${ }^{[18,19]}$ designed to measure the hygiene standards in all slaughterhouses and cutting plants in United Kingdom.

HAS is based on risk assessment, but is still to some extent subjective, seeks to facilitate the recognition of good hygiene and management practices and focus attention on those parts of the operation that are particularly significant in hygiene control ${ }^{[20]}$.

General headings and major sections (the appendix indicates relative score):

\section{RAW MATERIALS}

Raw material: Malt

Raw material: Hop

Raw material: Yeast

Raw material: Water

Wrapping and packaging

Labeling

Final product and transport

FACILITIES AND INFRASTRUCTURES

Facilities

Equipments

Storage silos

\section{HACCP}

Food handler's formation plan

Cleaning, disinfection, fumigation and maintenance plan Conditions of the potability of the water 


\section{HACCP system}

This assessment survey was conducted in a brewery located on the island of Tenerife (Canary Islands, Spain), with $831,100 \mathrm{hl}$ of production ${ }^{\text {[21] }}$.

Before the start of counselling, in the first visits was conducted the first assessment survey by the consulting veterinarian.

Over one year, the assessor conducted on a monthly visits to facilities, on-site assessing the existing issues, and notification to staff that could directly address the incidence, management and staff, presenting the same written a report and corrective measures suggested to them.

After a year, we proceeded to re-assess the sanitary conditions in the industry.

\section{Statistical analysis}

To analyze the evolution and impact of counselling on the hygienic-sanitary conditions in the industry, a set of 133 items grouped into 13 groups was measured before and after counselling. A portion of the scores moved in a range of 0 to 2 and other from 0 to 3 , but all were standardized to a scale of 0 to 10 . In each of the 13 groups, scores were summarized as means and standard deviations (pre and post). The variation of the overall score was compared with the Wilcoxon test for dependent data. A hypothesis test was considered statistically significant when the corresponding p-value was less than 0.05 . In each of the groups of items were obtained frequencies that improved after counselling.

\section{RESULTS AND DISCUSSION}

\section{A. Sanitary Hygienic Assessment}

A survey was conducted to assess the hygienic conditions of the company that took place in December 1 , 2010; and the following results were obtained:

\section{B. Brewery Facilities}

The section "Facilities" got very good classification, with 31 points when the maximum was 35 , as shown in Table 2. Brewery floors are tough, easy to clean and disinfect. The walls are smooth and impervious, easily cleaned. The doors are waterproof, glass and easy to clean and disinfect. Despite this, the roofs do not meet what is required in the questionnaire, as the machinery used is quite bulky so high as to the breadth with which the ceilings are high and do not allow cleaning them. Nor is it feasible to use elevators as there are numerous architectural barriers (stairs), which prevent the cleaning is effective.

TABLE II ASSESSMENT SCORES OF FACILITIES AND INFRASTRUCTURES, RAW MATERIALS AND HACCP ON 1/12/2010

\begin{tabular}{ccc}
\hline \multicolumn{3}{c}{ FACILITIES AND INFRASTRUCTURES } \\
\hline SECTIONS & Total score & Obtained score \\
Facilities & 35 & 31 \\
& & \\
Equipments & 25 & 25 \\
Storage silos & 40 & 38 \\
\hline TOTAL & 100 & 94
\end{tabular}

RAW MATERIALS

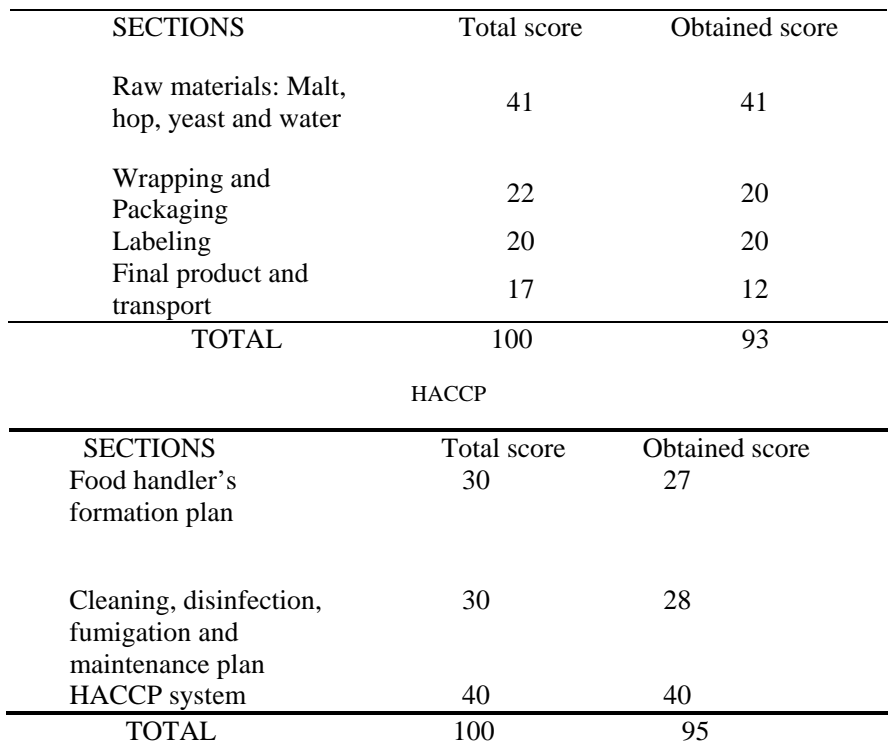

In work areas there are several points with piped water intakes but note that they are only cold water without the possibility of using hot water.

The section "Equipments" got the maximum rating on this assessment, as is visible in Table II and Figure 2. All equipments are made of materials suitable for food use. They are easy to clean because the operator is not directly involved in this process. Automated processes are handled through a controller that receives work orders via computer.

In relation to section "Storage silos", its classification, which is present in Table 2, was also very good with a total of 38 points when the maximum was 40 . The storage silos are one of the most critical places in the company. The difficulty in cleaning and disinfection is inside the silo. The silo has a cylindrical-conical form with an auger motor on top. Cleaning consists of its manual removing or with the malt powder that has been stored in a plastic shovel. Disinfection of the silo is made with carbon dioxide through a pipe connected to the silos, to that end, the silo must be located closed.

The valuation obtained in this survey was $94 \%$, meaning that the hygienic assessment is suitable. If this valuation was lower than $60 \%$ (this threshold set as $60 \%$ was established by the OHAPA and ULPGC specialists) we would have a case that the facilities and infrastructures would not be appropriate or suitable to the activity developed by the company, see Figure 2.

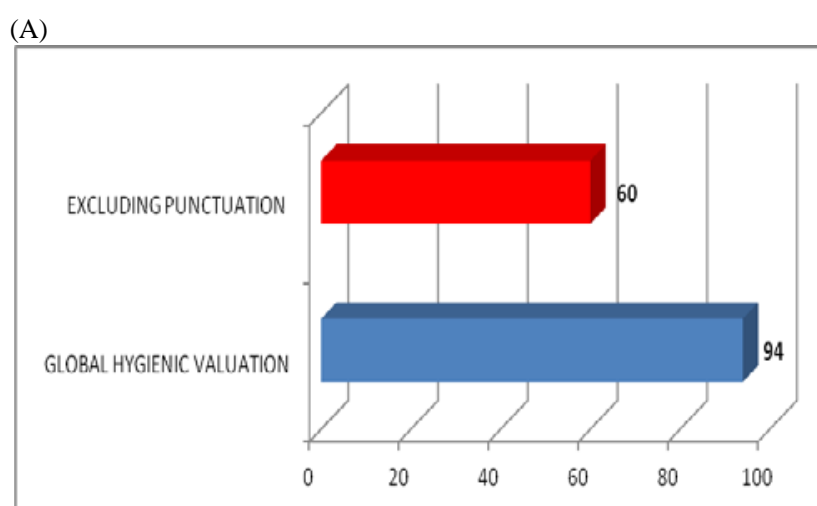


(B)

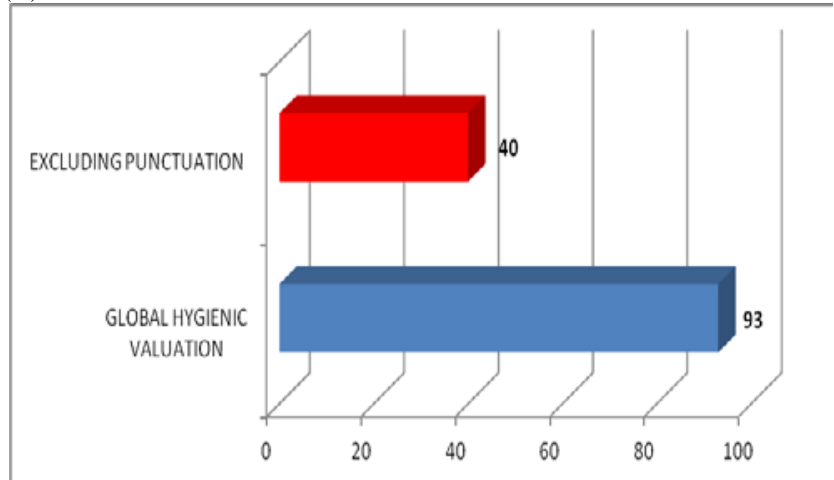

(C)

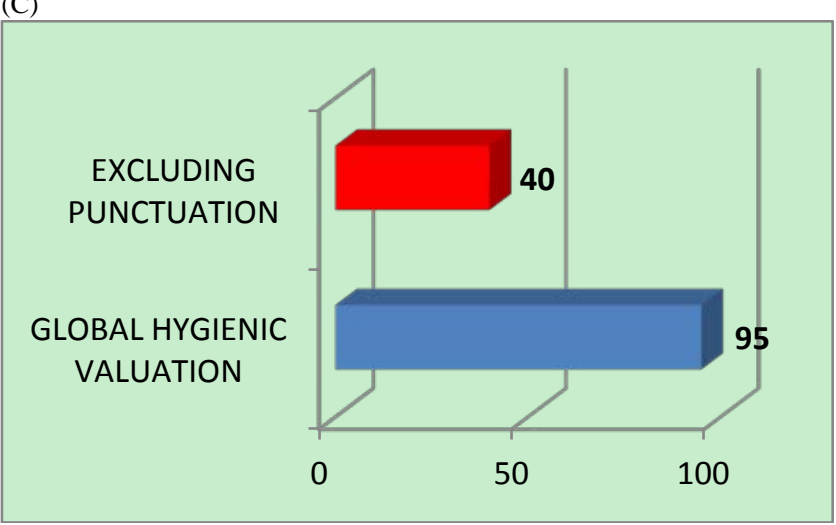

Fig. 2 Valuation obtained in the survey realized on 1/12/2010. Facilities and infrastructures (A); Raw materials (B); HACCP (C)

\section{Elaborated Product}

According to Table II, the section "Raw material" obtained the maximum score, noting that the company complies with the requirements. Providers have the appropriate certificates and operators of the company are responsible for the supervision of raw material and the cleanliness of the facilities.

Across the visualization of the Table II, is verified that the "Wrapping and packaging" paragraph has obtained a very good classification, 20 points when the maximum was of 22. "Wrapping and packaging" comply with the legal regulation, but is observed that the containers with returnable format are not stored in hygienic conditions. They are located in the courtyard outside the company.

As is visible in Table II, the section relating to "Labeling" got the maximum score; labeling is completely legible, with all the data required by Spanish law, it does not induce to any mistake.

In relation to the "Final product and transport", Table IIshows a high rank, with a total of 12 points when the maximum was 17 . Regarding the final product complies with the requirements of taking care of the hygiene and product rotation. In the stores they possess the system FIFO (first in - first out), that is to say, the first entering is the first one to going out. The goods are stored on metal shelves, identified in letters and numbers with easy location of products that expire soon. On the other hand, there are shortcomings in the transport of the product. At the time of the survey, there were several trucks with cardboard and plastic debris in the cargo area. Nor is there evidence of a cleaning of vehicles, just when the driver shows that it is dirty clean it. Clearly there is no record to review and register the vehicle cleaning. The rotation of loading and unloading of each vehicle which is fast with no time for such inspection. Nor is there a particular area for cleaning vehicles, only have one parking space per vehicle within the brewery compound without the possibility of an appropriate place for such cleaning.

In general lines, the global valuation of the hygiene at the company is very good. In this case, of hundred for hundred, the valuation is $93 \%$ as is demonstrated in Figure 2.

\section{Quality System}

The section "Food handler's formation plan” has a very good rating, with 27 points when the maximum was 30 , as can be seen in Table II. The staff of the departments of Production, Packaging, Quality Maintenance and Warehouse has the training of food handlers. The course is adapted to the reality of the company by the specific own risks of the brewing industry. The supervision of employees regarding the proper handling falls on middle management; it is observed that not all departments are equally sailing to meet this requirement.

The clothing of the workers is usually adequate and clean. What it was observed that when more workers enter the work site and in its output, wore the same clothes to work, thus, it follows that it is not exclusive use.

In relation to the "Cleaning, disinfection, fumigation and maintenance plan,” according to Table II, also got a very good rating of 28 points when the maximum was 30 . Overall there is good presence in the cleaning and disinfection of facilities. There is an outside company that is dedicated to disinfection, pest control and fumigation of the plant. The activities of this company are recorded by the share of the work that the brewery gets a copy. It is not clear that there is a person who supervises the work of this company.

Finally, the Table II also shows that the "HACCP System" received an excellent rating with the maximum score of 40 points, once they have recently renewed the triple certification in Quality, Environment and Prevention and all matters referred in the survey have been assessed by a certifying agency as suitable.

The score in the assessment of the brewery hygiene (HACCP) is 95\% (Figure 2).

The results regarded to the evolution and impact of counselling on the hygienic-sanitary conditions in the industry are summarized in Figures 3, 4 and 5. According to them, the overall variation is statistically significant $(\mathrm{p}<$ 0.001 ) which indicates a considerable evolution between the two assessments applied. 


\begin{tabular}{lcccc}
\hline & \multirow{2}{*}{$\begin{array}{c}\text { No of } \\
\text { evaluated } \\
\text { items }\end{array}$} & Srevious & Subsequent & $\begin{array}{c}\text { Item improvement } \\
\mathrm{n}(\%)\end{array}$ \\
\cline { 3 - 4 } & 15 & $7.7 \pm 2.8$ & $9.0 \pm 2.8$ & $6(40.0)$ \\
Facilities & 10 & $8.7 \pm 2.1$ & $10 \pm 0$ & $3(30.0)$ \\
Equipment & 7 & $9.4 \pm 1.5$ & $10 \pm 0$ & $1(14.3)$ \\
Storage Silos & 9 & $7.2 \pm 2.6$ & $9.7 \pm 0.8$ & $5(55.6)$ \\
Malt & 5 & $8.5 \pm 2.3$ & $10 \pm 0$ & $2(40.0)$ \\
Hop & 6 & $9.2 \pm 2.0$ & $10 \pm 0$ & $1(16.7)$ \\
Yeast & 4 & $10 \pm 0$ & $10 \pm 0$ & 0 \\
Water & 10 & $9.0 \pm 3.2$ & $9.0 \pm 3.2$ & 0 \\
Packaging & 13 & $9.8 \pm 0.7$ & $10 \pm 0$ & $1(7.7)$ \\
Labeling & 11 & $5.2 \pm 4.5$ & $8.2 \pm 4.0$ & $5(45.5)$ \\
Transport & 12 & $7.8 \pm 2.3$ & $9.4 \pm 1.9$ & $6(50.0)$ \\
FHFP 1 & 16 & $9.4 \pm 1.7$ & $9.7 \pm 1.2$ & $1(6.2)$ \\
CDFMP & 2 & $8.2 \pm 2.2$ & $9.9 \pm 0.4$ & $7(46.7)$ \\
HACCP & 15 & $8.4 \pm 2.7$ & $9.5 \pm 1.9$ & $38(28.6)$ \\
\hline Total $\dagger$ & 133 & & & \\
\hline
\end{tabular}

$(\dagger)$ The overall variation is significant $(\mathrm{p}<.001)$

1FHFP: Food Handler Formation Plan

${ }^{2}$ CDFMP: Cleaning, Disinfection, Fumigation and Maintenance Plan

Fig. 3 Summary of the results of the study

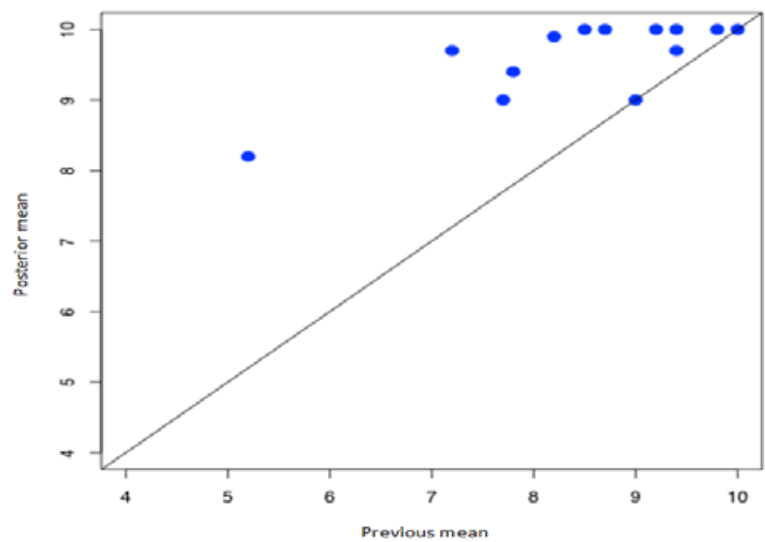

Fig. 4 Average of items before (abscissa) and after (ordinate) of the intervention. All the points are above the bisector, indicating increased score after counselling

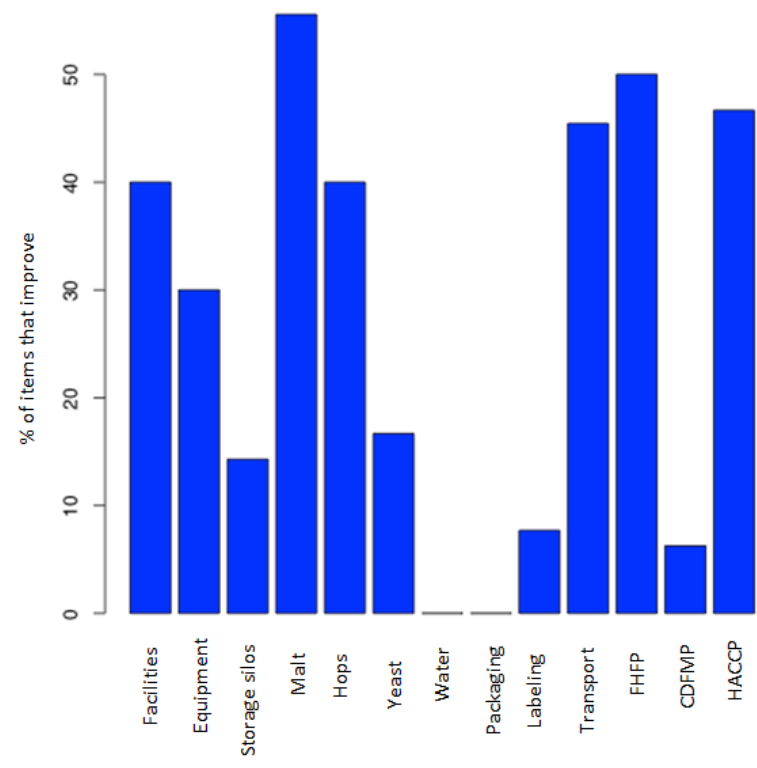

Fig. 5 Percentages of items that improve by survey group

\section{IV.CONCLUSIONS}

In this study, it was designed and tested a model of food risk assessment that allows an assessment of risks from the facilities and infrastructures, raw materials and HACCP plan for a brewery and this survey was employed to a brewery on the island of Gran Canaria with quite acceptable results that can serve as a model for future assessments in other factories in the sector. It was well demonstrated the importance of counselling and its impact on all the items assessed. Hygiene Assessment System Surveys are discussed in a framework of a quality assurance system in order to have a useful and effective tool for risk analysis.

\section{REFERENCES}

Canariasahora.es. (2011). Report on the sale of beverages in Spain. Available http://www.canariasahora.com/noticia/183847/ (Accessed 23 Feb. 2012).

Catarino, M., Mendes, A., Madeira, L. and Ferreira, A. (2006). Beer dealcoholization by reverse osmosis. Desalination 200:397-399.

Anonymous. (1995). Royal Decree 53/1995, of January 20, by approving the Technical and Health Regulations for the production, circulation and marketing of beer and liquid malt.

FAO. (1997). Recommended International Code of Practice, General Principles of Food Hygiene, CAC/RCP 1-1969, Rev. 3.

Hardwick, W.A. (1994). History and antecedents of brewing. In "Handbook of Brewing"; Hardwick,W.A.; .(Ed.); pp 3752, Marcel Dekker: New York.

Kunze, W. Technology Brewing and Malting, VLB Berlin, Germany, (1996).

Păcală, M.-L., Tita, O., Begea, M. and Sîrbu, A. (2009). HACCP study and validation by QMSFSM for brewing process application for training of students from food technologies, 5 Balkan Region Conference on Engineering and Business Education \& 2nd International Conference on Engineering and Business Education Sibiu, Romania, 15 - 17 October, 2009, Conference proceedings, 2009 (www.brcee.ro), 447-452.

Vaughan, A., O’Sullivan, T. and Sinderen, D. (2005). Enhancing the Microbiological Stability of Malt and Beer - A Review. Journal of the Institute of Brewing. 111(4), 355-371

Sohrabvandi, S., Mortazavian, A.M. and Rezaei, K. (2012). Health-Related Aspects of Beer: A Review. International Journal of Food Properties, 15:350-373.

Grant, H.L. (1977). Wort boiling. In The Practical Brewer, H.M. Broderick (ed.). Master Brewers Association of the Americas, Madison, Wisconsin, USA.; pp. 117-127.

Ahvenainen, J. and Kuhanen, J. (1993). Method for the fermentation of beer. U.S. Patent, 273,7,62, 1993.

Hardwick, W.A. (1994b). The properties of beer. In "Handbook of Brewing”. W.A. Hardwick, (Ed.), pp. 551-586, Marcel Dekker: New York.

Gerhauser, C. (2005). Beer constituents as potential cancer chemopreventive agents. European Journal of Cancer 41:1941-1954.

Bamforth, C.W. (2001). Nutritional aspects of beer. A review. Nutr. Res. 22:227-237.

Sohrabvandi, S. (2008). Optimization alcohol free beer production produced with restricted fermentation practice. D. Thesis, Tehran University, Tehran, Iran. 
Caluwaerts, H.J.J. (1995). Process for the manufacture of an alcohol-free beer having the organoleptic properties of a lager type pale beer. U.S. Patent 5, 384,135.

European Parliament and Council (1993). Council Directive 93/43/EEC of 14 June 1993 on the hygiene of foodstuffs.

Anonymous. (1996). Ministry of Agriculture, Fisheries and Food. UK Government.

Garcia Pinillos, R. and Jukes, D.J. (2008). Hygiene assessment system (HAS) scores - An analysis of the available data from English slaughterhouses. Food Control. 19: 806816 .

Hudson, W. R., Mead, G. C. and Hinton, M. H. (1996). Relevance of abattoir hygiene assessment to microbial contamination of British beef carcases. The Veterinary Record, December 14.

Compañía Cervecera de Canarias. (2012). Available at http://www.ccc.es. (Accessed 20 Apr 2012).

APPENDIX

Survey Model

\section{CONCEPT $=$ FACILITIES and INFRASTRUCTURES}

\section{FACILITIES}

2.1.1.- Waterproof and resistant floors easy to clean and disinfect

2.1.2.- If necessary, provided with adequate drainage

2.2.- Walls smooth, waterproof, easy to clean and disinfect

2.3.- Flush doors, easy to clean and disinfect

2.4.- The ceilings prevent accumulation of dirt and are easy to clean

2.5.-Adequate ventilation

2.6.- Adequate lighting, natural or artificial, in this second case protected

2.7.- In good condition of cleanliness

2.8.- In good condition of maintenance

2.9.- Sufficient and suitable devices for cleaning supplies and / or food

2.10.- Sufficient and suitable devices for cleaning of the facilities

2.11.- There are devices for cleaning and drying hands

2.11.1.- With hot and cold running water

2.11.2.- In sufficient number and near to the working place

2.11.3.- Armed with cleaning supplies and hygienic drying

33

22

22

22

30

33

33

22

33

22

22

22

21

22

22

$35 \quad 31$

\section{EQUIPMENTS}

3.1.1.- Corrosion resistant

3.1.2.- Easy to clean and disinfect

3.1.3.- In good condition of cleanliness

3.1.4.- In good condition of maintenance

3.1.5.- Constructed of materials suitable for food use

3.2.- If using work tools:

3.2.1.- Corrosion resistant

3.2.2.- Easy to clean and disinfect

3.2.3.- In good condition of cleanliness

3.2.4.- In good condition of maintenance

3.2.5.- Constructed of materials suitable for food use

4. STORAGE SILOS

\subsection{With sufficient capacity}

4.2. Constructed or lined with materials suitable for food use 


\begin{tabular}{lrr}
\hline 4.4. In good condition of cleanliness & 5 & 5 \\
4.5. In good condition of maintenance & 5 & 5 \\
4.6. Have adequate facilities for loading and unloading & 5 & 5 \\
4.7. Prevent access to the interior of insects and rodents & 10 & 10 \\
& 40 & 38
\end{tabular}

\section{RAW MATERIAL: MALT}

\section{CONCEPT $=$ RAW MATERIALS}

1.1.- Providers have the general health food registration in effect

1.2.- There is documentation proving their fitness for human consumption

1.3.- The raw material is accompanied by all required information in the labeling or documentation that accompanies each delivery

1.4.- There is documentation for the mycotoxin content of the raw material

1.5.- Visual control is performed upon receipt

1.6.- The storage time is controlled

1.7- Cleanliness of raw material:

1.7.1.- It is realized in good hygienic conditions

1.7.2.- It guarantees that there is separation of stones, metallic elements, other cereals, or remains of any another nature

1.7.3.- The maintenance is suitable

RAW MATERIAL: HOP

2.1.- Providers have the general health food registration in effect

2.2.- There is documentation proving their fitness for human consumption

2.3.- The raw material is accompanied by all required information in the labeling or documentation that accompanies each delivery

2.4.- The storage time is controlled

2.5.- The storage temperature of the product is appropriate $\left(1{ }^{\circ} \mathrm{C}-5^{\circ} \mathrm{C}\right)$

\section{RAW MATERIAL: YEAST}

3.1.- Providers have the general health food registration in effect

3.2.- The containers are in good hygienic conditions

3.3.- Proper handling of yeast

3.4.- Absence of pathogens

3.5.- Is kept away from light and moisture

3.6.- Sample is collected daily

\section{RAW MATERIAL: WATER}

4.1.- The water is fit for human consumption

4.2.- Absence of pathogens

4.3- The disinfection is adequate

4.4.- Daily sampling of water beer

\section{WRAPPING AND PACKAGING}

5.1.- The material used for wrapping is suitable for food use

5.2.- Providers of wrapping material have the general health food registration in effect

5.3.- The containers are new or have undergone a cleaning and disinfection if were reused 
5.5.- The wrapping is done in good hygienic conditions

5.5.1- Stop over 15 minutes, the circuit performs disinfection filler

5.5.2.- Every 2 hours is disinfected bottle filler

33

5.6. Is proceeded to the cleaning of equipment by changing the product to be wrapped

5.7. The packages are stored in good hygienic conditions (PALES PLAST)

5.8. The packaging is done in hygienic conditions

\section{LABELING}

6.1.- The name of the product is indicated correctly

6.2.- The list of ingredients is indicated correctly

6.3.- If they contain food additives they are indicated correctly

6.4.- The clear quantity is indicated correctly

6.5.- The date marked is correctly indicated

6.6.- The special storage conditions are correctly indicated

6.7.- The identification of the company is indicated correctly

6.8.- The lot is indicated correctly

6.9.- The origin is indicated correctly

6.10.- Mandatory labeling appears in Spanish

6.11.- All information is easily understandable, visible, legible and indelible

6.12.- The information is provided so as not to mislead the consumer

6.13.- There is a telephone number for consumers

\section{FINAL PRODUCT AND TRANSPORT}

7.1.- Storage is done in good hygienic conditions

7.2.- It is controlled the maximum time of storage

7.3.- Microbiological tests are undertaken periodically to include at least mesophilic aerobic plate count, mold, E. coli and Salmonella

7.4.- The vehicles are in good clean condition

7.5.- The vehicles are in good condition of maintenance

7.6.- There is a program of proper cleaning of vehicles

7.7.- It registers and checks the cleanliness of the vehicles

7.8-. Suitable site available for clean vehicles

7.9.- There are parking spaces for exclusive use

7.10.- The receptacles are used exclusively for this transport

7.11.- They clean the equipment used for loading and unloading

\section{CONCEPT $=$ HACCP}

FOOD HANDLER'S FORMATION PLAN

\begin{tabular}{lcc}
\hline 8.1.1.- It has an adequate training program & 3 & 3 \\
8.1.2.- There is a manager or training coordinator & 2 & 2 \\
8.1.3.- It contemplates the program of basic and specific needs of the activity and targets & 2 & 2 \\
8.1.4.- Includes a calendar, duration, content and location is given & 3 \\
8.1.6.- Are monitored and recorded properly handling practices & 3 \\
\hline
\end{tabular}

JLM Volume 1, Issue 3 October 2013 PP. 61-70 www.vkingpub.com/jlm @ American V-King Scientific Publishing 
8.1.7.- There is a record of corrective measures for detected irregularities

8.1.8.- There are records of the training and the frequency with which they are taught training

8.1.9.- The company certifies that the manipulators have training in food hygiene appropriate to their tasks

8.1.10.- Personal hygiene of food handlers is correct

8.1.11.- Handlers' clothing is appropriate, exclusive use and clean

8.1.12.- Absence of personal effects that could enter in touch with the food

8.1.13.- Absence of personnel that presents manifest signs of suffering disease that can be transmitted through food

\section{CLEANING, DISINFECTION, FUMIGATION AND MAINTENANCE PLAN}

2

8.2.1.- The storage of the products used is suitable

8.2.2.- The products are kept in their original containers or in others that do not induce to possible mistake in its use

8.2.3.- Storage of cleaning equipment and supplies is suitable

$$
2
$$

8.2.4.- There is an appropriate program of cleaning and disinfection

8.2.4.1.- It is carried out of correct form

8.2.4.2.- Register and review the operations

8.2.4.3.- The products used are suitable for use in the food industry

8.2.5- There is an appropriate program of pest control

8.2.5.1.- It is carried out of correct form

8.2.5.2.- It was carried out by authorized personnel

8.2.5.3.- An external company realizes it (to indicate)

8.2.5.4.- Register and review the operations

8.2.5.5.- The products used are suitable for use in the food industry

8.2.6.- There is a program of proper maintenance of facilities

8.2.6.1.- It is carried out of correct form

8.2.6.2.- Register and review the operations

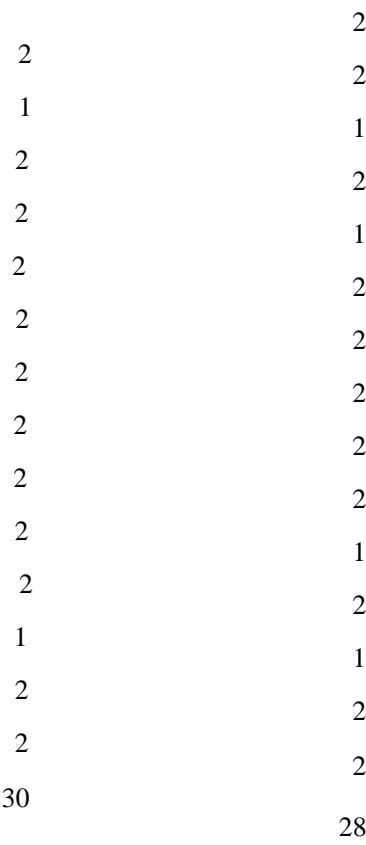

HACCP SYSTEM

9.1.- There is a written document that gathers the system of self-control

9.2.- This document has been reviewed by the inspector

9.3.- It is considered appropriate

9.4.-It is implanted

9.5.- Identifies hazards and establishes limits for contaminants, biotic and abiotic, in accordance with current regulations

9.6.- The critical control points are identified

9.7.- There is an efficient monitoring of critical control points

9,8.- There are remedies for when the critical control point is out of control

9.9.- The records of control are completed

9.10.- There is a verification procedure to demonstrate that the system is effective

9.11.- There is one person responsible for the system of self-control

9.12.- It has a product traceability system in place

9.12.1.- Defines the scope to include suppliers, customers and processes

\section{5}

2

3

9.12.2.- Includes procedures adapted for the location, immobilization and / or retreat of products 